\title{
Pengembangan E-Modul Materi Pisces Kelas X SMA/MA dengan Konteks Potensi Pesisir Jembrana
}

\author{
Mila Auliya ${ }^{1}$, Ira Nurmawati ${ }^{*}$ \\ ${ }^{1}$ Program Studi Tadris Biologi, FTIK, IAIN Jember \\ * E-mail: nurmawati ira@yahoo.com
}

\begin{abstract}
Abstrak
Penelitian ini bertujuan untuk mendeskripsikan kevalidan dan kepraktisan siswa terhadap e-modul materi pisces untuk siswa kelas X SMA/MA. E-modul yang dikembangkan berbasis android appyet dengan konteks potensi daerah pesisir Jembrana, Bali. Jenis penelitian yang dilakukan ini adalah Research and Development (R\&D) dengan model ADDIE (Analysis, Design, Development, Implementation dan Evaluation). Berdasarkan hassil validasi e-modul yang dilakukan oleh ahli materi diperoleh hasil sebesar $85,77 \%$ dengan kategori valid, dan hasil validasi oleh ahli media diperoleh hasil sebesar 90,13\% dengan kategori sangat valid dan hasil validasi oleh guru biologi sebesar $100 \%$ dengan kategori sangat valid. Adapun hasil angket respon siswa menunjukkan hasil sebesar 93,64\% dengan kategori sangat praktis. Berdasarkan hasil validasi dan angket respon siswa tersebut, dapat disimpulkan bahwa e-modul berbasis android appyet dengan konteks potensi daerah pesisir Jembrana pada materi pisces sangat valid dan sangat praktis sehingga dapat digunakan sebagai bahan ajar pembelajaran biologi siswa kelas X SMA/MA.
\end{abstract}

Kata Kunci: Appyet, Bahan Ajar Biologi, E-modul, Pesisir Jembrana.

\section{PENDAHULUAN}

Guru adalah orang yang paling berperan penting di dalam proses pembelajaran karena guru bertugas dalam merencanakan, melaksanakan, dan mengevaluasi hasil pembelajaran siswa. Salah satu upaya yang dapat dilakukan guru untuk membentuk suatu kelas yang aktif dan interaktif adalah menyediakan bahan ajar yang lebih menarik dan inovatif untuk menunjang pembelajaran karena hal ini dapat membuat siswa menjadi lebih tertarik atau termotivasi belajar. Bahan ajar merupakan segala bahan yang dapat mengandung isi materi baik informasi, alat, maupun teks yang disusun secara sistematis yang digunakan dalam proses pembelajaran. (Asiyani, 2019:3). Misalnya seperti menggunakan bahan ajar berupa modul.

Modul adalah salah satu bahan ajar yang dapat dimanfaatkan siswa secara mandiri, serta dapat digunakan kapanpun dan dimanapun sesuai dengan kebutuhan dari siswa. Modul yang diberikan oleh sekolah saat ini kebanyakan masih dalam bentuk cetak. Sedangkan teknologi telah mengalami perkembangan, bahkan telah memberikan dampak positif bagi dunia pendidikan. Sehingga dengan adanya perkembangan teknologi dapat dimanfaatkan dengan menjadikan modul tersebut menjadi modul yang berbasis elektronik. 
Biologi adalah ilmu yang berkaitan dengan alam, dan pembelajaran biologinya bertujuan untuk memberitahukan informasi, pikiran-pikiran dan nilai-nilai yang berisi fakta, konsep dan proses yang terjadi di alam agar siswa mampu memahami alam sekitar. Melalui pembelajaran biologi tersebut, siswa diharapkan mampu mengembangkan kompetensi, mencari tahu dan berbuat berdasarkan apa yang telah diketahui secara langsung atau berdasarkan pengalaman langsung siswa (Pratama, dkk, 2018: 2). Siswa dapat memperoleh pengalaman langsung tentang alam atau pembelajaran biologi dari potensi daerah yang dimiliki oleh daerah siswa. Potensi daerah dapat dimanfaatkan untuk guna mendukung desentralisasi pendidikan. Seperti potensi daerah yang dimiliki oleh daerah pesisir Jembrana yang dapat dimanfaatkan sebagai sumber belajar bagi siswa yaitu karena daerah pesisir Jembrana memiliki keanekaragaman pada piscesnya. Menurut Magfiroh, dkk (2020) wilayah pesisir tersebut merupakan potensi yang cukup besar bagi pengambengan sektor perikanan dan juga didukung dengan adanya pelabuhan perikanan yang merupakan pelabuhan perikanan terbesar di Provinsi Bali.

Dengan demikian hal ini perlu dimanfaatkan untuk dijadikan sebagai sumber belajar siswa dibidang biologi. Karena dengan adanya proses pembelajaran yang sumber belajarnya diambil dari materi potensi daerah akan membuat pembelajaran jauh lebih nyata dan pada hakikatnya sumber belajar dalam pembelajaran sains bersumber dari lingkungan (Pradieta dkk., 2017).

Berdasarkan hasil analisis kebutuhan siswa yang dilakukan oleh siswa kelas $X$ IPA MAN 3 Jembrana bahwa siswa membutuhkan bahan ajar yang dapat menyajikan materi dalam satu kesatuan seperti antara teks, gambar dan video pembelajaran. Sebanyak 52,3\% siswa setuju membutuhkan bahan ajar yang lebih menarik dan siswa setuju sebanyak $71,4 \%$ jika materi yang disajikan dalam modul dapat dilihat secara langsung dikehidupan sehari-hari, hal tersebut menjadikan siswa sangat setuju sebanyak $85,7 \%$ mereka akan lebih memahami materi yang dipelajari.

Selain itu, menurut guru MAN 3 Jembrana pada masa pandemi terdapat kendala di dalam proses pembelajaran yaitu kendala terkait vinansial dan kurangnya dalam pengawasan siswa yang salah satunya pengawasan di dalam proses ujian mengakibatkan hasil akhir yang diperoleh berbeda pada saat proses pembelajaran langsung dan daring. Guru telah memiliki kinerja khusus untuk mengatasi masalah tersebut tetapi tetap masih mengalami kendala di dalam proses penerapannya.

Dari uraian-uraian diatas masih perlunya dilakukan pengembangan lebih lanjut akan bahan ajar yang telah digunakan oleh sekolah MAN 3 Jembrana yaitu dengan mengembangkan modul elektronik berbasis android appyet, karena appyet akan dilengkapi dengan menumenu, gambar-gambar dan video yang menampilkan potensi daerah pesisir Jembrana tersebut. Sehingga dengan 
banyaknya menu yang dapat ditampilkan akan mempermudah siswa dalam mencari kebutuhannya di dalam pembelajaran.

Mata pelajaraan Biologi selain karakteristik materinya berhubungan dengan fakta-fakta ilmiah atau lingkungan, juga memerlukan bahan ajar yang dapat mendukung pembuktian pembelajaran secara nyata, seperti e-modul yang dikembangkan dengan berbasis andorid appyetyangdapatmenampilkan materiyang berisikan fakta ilmiah dari potensi daerah pesisir Jembrana yang dimiliki. Maka hal inilah yang membuat modul elektronik berbasis android appyet dianggap akan lebih menarik dibandingkan dengan modul elektronik yang ada di sekolah.

Tujuan dari penelitian ini yaitu: 1.) Mendeskripsikan kevalidan e-modul berbasis android appyet dengan konteks potensi daerah pesisir Jembrana pada materi pisces untuk ssiswa kelas X SMA/ MA dan 2.) Mendeskripsikan kepraktisan e-modul berbasis android appyet dengan konteks potensi daerah pesisir Jembrana pada materi pisces untuk siswa kelas $X$ SMA/MA.

\section{METODE}

Jenis penelitian yang dilakukan ini adalah Research and Development (R\&D) dengan model ADDIE (Analysis, Design, Development, Implementation, and Evaluation), namun, dikarenakan kondisi yang masih berada dalam masa pandemi covid-19 dan keterbatas waktu serta biaya, tahap yang bisa terlaksana di lapangan hanya tiga, yaitu analisis, desain, dan pengembangan, sedangkan tahap implementasi dan evaluasi tidak bisa terlaksana. Berikut dapat dijelaskan tahapan yang dilakukan selama melaksanakan penelitian:

\section{a. Analisis (analysis)}

Pada tahap ini dilakukan dua kegiatan yang terdiri dari analisis kinerja dan analisis kebutuhan. Pada kegiatan analisis kinerja peneliti melakukan observasi dan wawancara kepada guru biologi dan siswa untuk mengetahui dan mengklasifikasikan permasalahan yang dihadapi di sekolah yang berkaitan dengan bahan ajar yang digunakan dan keterlaksanaan proses pembelajaran, kemudian menemukan solusi dengan mengembangkan bahan ajar.

Sedangkan pada kegiatan analisis kebutuhan, peneliti membagikan angket analisis kebutuhan bahan ajar kepada guru biologi dan siswa untuk menentukan jenis bahan ajar yang diperlukan oleh siswa dalam kegiatan pembelajaran, yaitu bahan ajar yang dapat membuat siswa menjadi lebih tertarik, aktif, dan lebih mudah memahami konsep yang dipelajarinya. Selain melakukan observasi terhadap kondisi di sekolah, peneliti juga melakukan observasi ke Tempat Pelelangan Ikan (TPI) di Jembrana untuk mengidentifikasi keanekaragaman spesies ikan tangkapan nelaayan di pantai pesisir Jembrana.

\section{b. Desain (Design)}

Pada tahap desain ini, dilakukan langkah-langkah sebagai berikut; (1) memilih layanan online yang digunakan untuk membuat e-modul, (2) membuat menu-menu yang akan ditampilkan pada e-modul pada tampilan home, (3) mengisi 
masing-masing menu yang sudah dibuat sesuai dengan isi bahan materinya mulai dari kI, KD, indikator, materi bahan ajar yang berisikan pengertian, teks, dan gambar sesuai hasil identifikasi ikan tangkapaan di daerah pesisir Jembrana, soal-soal yang akan dijawab oleh siswa, dan yang terakhir adalah mengisikan profil pengembang bahan ajar.

c. Pengembangan (Development)

Pada tahap pengembangan ini terdiri atas; (1) pembuatan $e$-modul sesuai dengan desain yang telah dibuat sebelumnya menggunakan aplikasi Appyet, melakukan validasi ahli media, validasi ahli materi, dan validasi praktikal, (3) revisi media dari para ahli dan praktisi, (4) merevisi media berdasarkan masukan dari para validator, (5) melakukan uji coba terbatas, (6) melakukan revisi berdasarkan hasil angket respon dan masukan siswa.

Pada tahap implementasi dan evaluasi tidak bisa dilaksanakan dikarenakan tidak adanya pembelajaran tatap muka di sekolah selama masa pandemi covid-19 dan keterbatasan waktu serta biaya, sehingga penelitian ini terbatas pada tahap pengembangaan. Berdasarkan tahap pengembangan yang telah dilakukan, diperoleh hasil penelitian berupa data kualitatif dan data kuantitatif, data kualitatif diperoleh dari kritik dan saran dari produk yang dikembangkan sedangkan data kuantitatif diperoleh dari data yang diolah dari rumusan angka.

Data kuantitatif yang diperoleh dari angket validasi dianalisis dengan menggunakan perhitungan rata-rata skor yang diperoleh dari para validator dengan rumus Akbar (2013) sebagai berikut :

$$
V a=\frac{T S e}{T S h} \times 100 \%
$$

\section{Keterangan}

Va = presentase validitas oleh validator

TSe $=$ total skor maksimal (nilai hasil maksimal yang di harapkan)

TSh $=$ total skor empiris (nilai hasil uji yang diperoleh validator)

Selanjutnya seluruh data presentase penilaianyang diperoleh diubahmenjadi data kuantitatif deskriptif yang menggunakan kriteria validitas. Kriteria kualitas bahan ajar e-modul dapat dilihat pada Tabel 1 berikut.

Tabel 1. Kriteria kevalidan materi dan media

\begin{tabular}{cc}
\hline Skor Rata-rata & Kategori Validitas \\
\hline $25,00-40,00$ & Tidak Valid \\
$41,00-55,00$ & Kurang Valid \\
$56,00-70,00$ & Cukup Valid \\
$71,00-85-00$ & Valid \\
$86,00-100,00$ & Sangat Valid \\
\hline
\end{tabular}

(Akbar, 2013)

Adapun data respon siswa diperoleh dari jumlah skor angket respon siswa yang kemudian dianalisis menggunakan rumus sebagai berikut;

$$
P=\frac{f}{n} \times 100 \%
$$

\section{Keterangan}

$\mathbf{P}=$ Persentase respon siswa

$f=$ Skor yang diperoleh

$n$ = Skor Keseluruhan

Setelah diperoleh persentase dari skor angket respon siswa, selanjutnya berdasarkan tingkat respon siswa pada tabel 2 (Sudijono,2008) dalam (Handayani, dkk., 2019). 
Tabel 2. Kriteria respons siswa

\begin{tabular}{cc}
\hline Skor Rata-rata & Kategori Validitas \\
\hline $\mathrm{P} \leq 25,00 \%$ & Sangat Tidak Praktis \\
$25,00 \%<\mathrm{P} \leq 43,75 \%$ & Tidak Praktis \\
$43,75 \%<\mathrm{P} \leq 62,50 \%$ & Kurang Praktis \\
$62,50 \%<\mathrm{P} \leq 81,25 \%$ & Praktis \\
$\mathrm{P}>81,25 \%$ & Sangat Praktis \\
\hline
\end{tabular}

\section{HASIL DAN PEMBAHASAN}

Penelitian dan pengembangan (Research $\mathcal{E}$ Development) merupakan metode atau proses yang digunakan untuk memvalidasi dan mengembangkan produk. Produk yang dihasilkan berupa e-modul berbasis android appyet dengan konteks potensi daerah pesisir Jembrana. E-modul memiliki lebih banyak kelebihan dibandingkan dengan modul cetak yaitu seperti sifatnya yang interaktif, memudahkan dalam navigasi, dapat menampilkan atau memuat gambar, audio, video, dan animasi serta dilengkapi dengan tes formatif yang memungkinkan umpan balik otomatis dengan segera (Arsal, dkk. 2019), sehingga e-modul cocok dikembangkan di dalam proses pembelajaranjarak jauh dikarenakan sifatsifat yang dimiliki.

E-modul dikembangkan melalui layanan online Appyet, yang mana Appyet merupakan salah satu aplikasi berbasis web untuk dioperasikan pada android. Pada aplikasi Appyet, tidak ada pemrograman sama sekali dalam pembuatan aplikasi android, semua proses pemrograman akan dilakukan oleh Appyet setelah membuat beberapa pengaturan yang dibutuhkan (Sanjaya, dkk, 2019). Selain itu pada e-modul juga dimasukkan materi yang membahas potensi daerah pesisir Jembrana berupa ikan konsumsi hasil tangkapan para nelayan di daerah pesisir Jembrana.

Jembrana merupakan daerah yang berbatasan langsung dengan selat Bali di sebelah barat, Samudera Indonesia di sebelah selatan, serta memiliki garis pantai yang lebih dari $80 \mathrm{~km}$, dan Jembrana memiliki perairan laut seluas \pm 604,24 $\mathrm{km} 2$. Dengan letak geografis yang dimiliki tersebut usaha kelautan dan perikanan yang ada di Jembrana sangat dikenal di kalangan masyarakat Bali (Astarini, dkk, 2010), sehingga ini membuktikan bahwa pesisirJembranamemilikipotensidibidang biologi yaitu adanya keanegaraman jenis ikan atau Pisces.

Pisces adalah sebutan umum yang dipakai untuk ikan atau sebutan nama superkelas, dan nama dari kata latin (Jasin, 1988). Pisces yang ditemukan pada daerah pesisir daerah Jembrana dapat dilihat pada Tabel 3.

Berdasarkan Tabel. 3 tersebut, dapat diketahui bahwa masing-masing spesies ikan memiliki karakteristik yang berbeda dan deskripsinya masing-masing disajikan pada materi dalam e-modul, sehingga materi yang disajikan pada e-modul memang bersumber dari potensi daerah pesisir Jembrana. Ini merupakan sarana belajar yang membantu hubungan antara pengetahuan yang dimiliki dengan penerapan dalam kehidupan. Dikarenakan pada pendidikan perlu tersedia aneka sumber belajar yang mudah diperoleh untuk kegiatan belajar secara individu maupun kelompok sehingga dapat membantu mengaitkan materi yang dipelajari dengan kontes dunia nyata (Alimah, dkk, 2018). 
Indonesian Journal of Mathematics and Natural Science Education, 2 (1), 2021

Mila Auliya, Ira Nurmawati

Tabel 3. Berbagai spesies ikan konsumsi yang ditangkap oleh nelayan di daerah pesisir Jembrana

\begin{tabular}{|c|c|c|}
\hline No & Gambar Ikan & Nama Spesies \\
\hline 1 & & $\begin{array}{l}\text { Sardinella lemuru } \\
\text { (ikan lemuru) }\end{array}$ \\
\hline 2 & & $\begin{array}{l}\text { Rastrelliger kanagurta } \\
\text { (ikan banyar) }\end{array}$ \\
\hline 3 & & $\begin{array}{c}\text { Decapterus macrosoma } \\
\text { (ikan layang) }\end{array}$ \\
\hline 4 & & $\begin{array}{l}\text { Leiognathus bindus } \\
\text { (ikan cotek) }\end{array}$ \\
\hline 5 & & $\begin{array}{l}\text { Eulthynnus affinis } \\
\text { (ikan tongkol) }\end{array}$ \\
\hline 6 & & $\begin{array}{c}\text { Anodontostoma selangkat } \\
\text { (ikan lentreng) }\end{array}$ \\
\hline 7 & & $\begin{array}{l}\text { Selar crumenophthalmus } \\
\text { (ikan mata belo) }\end{array}$ \\
\hline 8 & & $\begin{array}{l}\text { Scomber scombrus } \\
\text { (ikan makarel) }\end{array}$ \\
\hline
\end{tabular}

Berdasarkan hasil validasi oleh para ahli diketahui bahwa persentase skor validasi oleh ahli materi sebesar $81,03 \%$ dengan kategori valid dan yang kedua memperoleh hasil sebesar 90,51\% sehingga memproleh rata-rata persentase sebesar $85,77 \%$ dengan kategori valid, untuk hasil validasi oleh ahli media pertama memperoleh hasil sebesar $96,71 \%$ dengan kategori sangat valid dan yang kedua memperoleh hasil sebesar 83,55\% sehingga memperoleh hasil rata-rata sebesar 90,13\% dengan kategori sangat valid serta berdasarkan hasil validasi praktikal oleh guru biologi diperoleh skor presentase sebesar $100 \%$ dengan kategori sangat valid.

Adapun pada saat dilakukan uji coba skala terbatas kepada 8 orang siswa diperoleh presentase sebesar 93,64\% dengan kriteria sangat praktis.

\section{SIMPULAN}

Berdasarkan hasil penelitian dan pembahasan di atas, dapat diperoleh kesimpulan bahwa: (1.) E-modul dengan konteks potensi daerah pesisir Jembrana 
yang dikembangkan berbasis aplikasi Appyet masuk kategori valid berdasarkan hasil validasi oleh ahli materi dengan ratarata persentase sebesar $85,77 \%$, ahli media memperoleh rata-rata sebesar $90,13 \%$ dengan kategori sangat valid, guru sebesar $100 \%$ dengan kategori sangat valid, (2.) Kepraktisan e-modul yang dilihat dari respon siswa menunjukkan bahwa skor presentase respon siswa terhadap e-modul sebesar 93,64\% dengan kriteria sangat praktis. Berdasarkan uraian tersebut, maka $e$-modul berbasis android appyet dengan konteks potensi daerah pesisir Jembrana pada materi pisces dinyatakaan valid dan praktis.

\section{DAFTAR PUSTAKA}

Akbar, Sa'dun. (2013). Instrumen Perangkat pembelajaran. Bandung: PT Remaja Rosdakarya.

Alimah Deni Muttah, AT. Hendrawijaya \& Deditiani Tri Indrianti. (2018). Pengaruh Pemanfaatan Potensi Lokal Sebagai Sumber Belajar Terhadap Program Pendidikan Aksaraan di Kabupaten Jember. Pendidikan Luar Sekolah 2018; 2(1): 2624.

Arsal Muhammad, Muhammad Danial \& Yusminah Hala. (2019). Pengembangan Media Pembelajaran E-Modul materi Sistem Peredaran Darah pada kelas XI MIPA SMAN 6 Baru. Prosiding Seminar Nasional Biologi 2019; VI(435): 435.

Asiyani, Yunita. (2019). Pengembangan Handout Berbasis Elektronik Menggunakan Teknik Mnemonik Akrostik pada Materi Keanekaragaman Hayati Untuk Peserta Didik Kelas X Di SMA/ MA. Skripsi, Universitas Islam Negeri Radeng Intan Lampung.

Astarini Ida Ayu \& Apri I. Supii. (2010). Kajian Kesesuaian Wilayah pesisir Jembrana-Bali Untuk Budidaya Rumput Laut. Dalam Penelitian Masalah Lingkungan di Indonesia, 44. Ikatan Ahli teknik Penyehatan dan Lingkungan Indonesia (IATPI).
Handayani Try Lisa, Sugianto \& hadi Susanto. (2019). Pengembangan Modul Pembelajaran Berbentuk Pop-Up dan Smash Book Materi Sifat Cahaya Bagi Siswa Penyandang Disabilitas Rungu. Unnes Physis Education Journal. 2019; 8(1): 11.

Jasin, Maskoeri. (1984). Sistematik Hewan: (Invertebrata dan Vertebrata). Surabaya: Sinar Wijaya.

Magfiroh Wilda \&Shofia. (2020). Strategi Nafkah Istri Nelayan Buruh di Desa Pengambengan Kecamatan Negara Kabupaten Jembrana. Sosial Ekonomi Pertanian2020; 13(1): 76-77.

Pratama Miko, Asni Johari \&Jefri Marzal. (2018). Pengembangan E-modul Biologi Berbasis Potensi Daerah Kerinci pada materi Plantae dan Animalia. Edu Sains.2018; 7(2): 2.

Pradietha Ekapty Tyas, Meilinda \& Khoiron Nazip. (2017). Identifikasi Materi Lokal sebagai Sumber Belajar Sains Biologi SMP di Kabupaten Muara Enim. Ditampilkan di Universitas Sriwijaya: 115.

Sanjaya Ridwan, Jason Canggayuda, Devina Gunadi \& Simeon Bensona. (2019). Mudah Membuat Aplikasi Pemasaran Digital 360 Derajat. Jakarta: PT Elex Meida Komputindo Kompas Gramedia.

\section{PROFIL SINGKAT}

Penulis pertama bernama Mila Auliya lahir di Bali pada tanggal 8 Juli 1999. Merupakan mahasiswa Prodi Tadris Biologi FTIK IAIN Jember masuk angkatan 2017 dan lulus tahun 2021. Penulis kedua adalah Ira Nurmawati, S.Pd., M.Pd., Dosen Biologi Dasar yang sampai saat ini masih aktif mengajar di Tadris Biologi FTIK IAIN Jember. 